\title{
IDŐJÁRÁS
}

Quarterly Journal of the Hungarian Meteorological Service

Vol. 125, No. 1, January-March, 2021, pp. 137-149

\section{Evapotranspiration and yield components of soybean}

\author{
Angela Anda*, László Menyhárt, and Brigitta Simon \\ Hungarian University of Agriculture and Life Sciences, Gödöllö \\ Georgikon Campus of Keszthely \\ Festetics György út 7, 8360 Keszthely, Hungary
}

*Corresponding authorE-mail: anda.angela@uni-mate.hu

(Manuscript received in final form April 3, 2020)

\begin{abstract}
Observation was conducted to determine the impact of water deprivation under flowering on the yield components of soybean at Keszthely, in the growing seasons between 2017 and 2018. The soybean represents an artificial ecosystem in this study. Three water levels designated as full watering in traditionally operated evapotranspirometer (ET), water withdrawal under crop flowering in modified evapotranspirometer (RO), and rainfed (P) crops were used. In RO treatments, the crops received half of the water based on the amount of unlimited water supply. Irrespective of variety, the highest water uses were obtained in ET, while the lowest ones were observed in RO over both growing seasons. Surprisingly, in spite of different variety standards provided by the crop breeders, and irrespective to water supply, no significant impact in actual evapotranspiration rate, $E T_{a}$, between the two varieties was observed. Significant impact in soybean water losses between the treatments was observed in RO as compared to the evapotranspiration of crops with unlimited watering.

There was no significant difference in yield components between soyabean varieties of rainfed treatments. As compared to variety Sigalia (Sig), variety Sinara (Sin) produced better yield in unlimited water level over 2017 weather conditions, and its seed had greater oil and lower protein content in RO treatment in 2018 conditions.
\end{abstract}

Key-words: soybean, evapotranspiration, seed yield, yield components 


\section{Introduction}

Evapotranspiration rate $\left(E T_{a}\right)$, the largest energy consumer of crop canopies' water budget, is also the link between mass and energy exchanges. Solar radiation interacts with $\mathrm{ET}_{\mathrm{a}}$ in a complex manner that makes this investigation very complex. Anapalli et al. (2018) called the attention for the missing research work integrating crop water demands $\left(E T_{a}\right)$ with available water supplies (rainfall and irrigation) in water management decision making. Therefore, new information related to plant $E T_{a}$, including soybean, is required to determine robust solutions for irrigation scheduling even in Hungary.

Irrigated soybean's $E T_{a}$ sum of $650 \mathrm{~mm}$ by Candogan et al. (2013) in Turkey was close to the water loss result in the treatment with unlimited watering. However, $E T_{a}$ totals of rainfed soybean amounting $300 \mathrm{~mm}$ in China (Wei et al., 2015), agreed with those results of water withdrawn one in this observation.

Soybean (Glycine max (L.) Merr.) is not the most important arable crop in Hungary occupying of about 50-60 thousand ha harvest area, that account for less than $1 \%$ of the total crop growing area. Nevertheless, the percentage of soybean growing area, among other arable crops, is permanently increasing. Nowadays, the majority of soybean is seeded under rainfed conditions. Due to the local impacts of global warming, the uneven seasonal distribution of precipitation in Hungary, the increasing importance of irrigation can be predicted in the near future. The high protein and oil content of the seeds make this crop irreplaceable source of feed for livestock, nutrients for human, and biofuel resources as well (Aydinsakir, 2018). The number of soybean seed users is increasing worldwide.

The most sensitive stage of soyabean to water deficit is the flowering. Kross et al. (2015) reported that soybean was more susceptible to extreme weather conditions between reproductive stages R4 and R6 (flowering and pod formation), when water deficiencies resulted in significant seed loss. Reduction in soybean yield varied widely from 24\% (Momen et al., 1979) to 45\% (Candogan et al., 2013) due to the lack of water during flowering. Limiting water is the main factor that contributes to the potential yield decline under field conditions. Although the quadratic relationship obtained through comparison between seed yield and $E T_{a}$ totals reported by Candogan et al. (2013) should also be accounted.

The aim of the study was to investigate the effect of soybean's water deprivation on the seed yield and its components. Soybean's growth indicators applied in the analysis were the total aboveground biomass (TDM), shoot dry matter $(D M)$, seed yield, 1000-seed weight, protein and oil contents. Out of these six variables, the protein and oil contents are qualitative traits, while all the remaining four ones are quantitative traits. These properties are affected by water stress, and they are indicative of final soybean production including seed yield. This analysis served as an example for crop-water relation in a such artificial (field grown) ecosystem as the soybean is. 


\section{Materials and methods}

The study of actual evapotranspiration, $E T_{a}$, and yield components in soybean (Glicine max, (L.) were carried out at the Agrometeorological Research Station, ARS, Keszthely, during the growing seasons between 2017 and 2018. Two soybean varieties Sinara (Sin) and Sigalia (Sig), widely cultivated in Hungary, have different water demands; Sin is a water stress-tolerant variety, while Sig is bred for "normal" weather conditions.

Three water levels are included in the study:

- unlimited watering in evapotranspirometer's growing chambers (ET),

- water deprivation in half; water supply of modified evapotranspirometers were restricted to every second day during flowering (RO), and

- rainfed crops $(\mathrm{P})$.

In case of RO, the rainfall was excluded by means of mobile rainout shelters ( $2.5 \mathrm{~m}$ long, $4.5 \mathrm{~m}$ wide, $2-2.5 \mathrm{~m}$ height). The technical solution of the shelters and the operation of the evapotranspirometer in $\mathrm{RO}$ were documented in Anda et al. (2019).

Due to the fixed nature of the evapotranspirometer, six growing chambers of Sin and six growing chambers of Sig were arranged in two complete blocks with three replications on the northern side of the ARS. Rainfed plots, P, were placed behind the block of the evapotranspirometers $(50 \mathrm{~m}$ wide and $60 \mathrm{~m}$ long for each soybean variety).

To measure the daily evapotranspiration of soybean, a Thornthwaite-Mather type compensation evapotranspirometer was used. Presentation in water losses of different treatments was based on phenological phases. Daily water uses were also summed up for the whole vegetation period.

At the ARS of Keszthely (latitude: $46^{\circ} 44^{\prime} \mathrm{N}$, longitude: $17^{\circ} 14^{\prime} \mathrm{E}$, elevation: $124 \mathrm{~m}$ above sea level), a QLC-50 climate station (Vaisala, Helsinki, Finland) with a pyranometer (Kipp \& Zonen Corp., Delft, the Netherlands) are operational. Combined air temperature $\left(T_{a}\right)$ and humidity sensors are placed at a standard height of $2 \mathrm{~m}$ above the surface level. Signals from meteorological sensors are collected every 2 seconds, and 10-min averages are logged.

The crops were sown at the end of April in 2017, and at the beginning of May in 2018 applying conventional tillage (the plant density was 40 plant $\mathrm{m}^{-2}$; the harvest population was approximately $25,000-30,000$ plants $\left.\mathrm{ha}^{-1}\right)$. Phenological phases were recorded using the scale of Fehr and Caviness (1977). Parallel with evapotranspirometer's growing chambers, randomly selected five subplot's $(2 \mathrm{~m} \times 2 \mathrm{~m})$ aboveground biomass $(T D M)$ was harvested in each variety at the beginning of each September. TDM was oven-dried at $65^{\circ} \mathrm{C}$ for constant weight. Seed of soybean was separated from other yield components through threshing the pods by hand. Their weights were adjusted to $13 \%$ moisture. 1000-grain 
weight was also weighed. Inframatic 9200 NIR Grain Analyzer (PerkinElmer, US) was used to determine the protein and oil content of seeds on dry-matter basis.

\section{Used statistics}

Principal component analysis (PCA) was used to visualize the data observed in the 6-dimensional space of the yield variables (TDM, shoot dry matter (DM), seed yield, 1000-grain weight, protein and oil contents). The PCA analysis is performed on a data table representing observations described by several dependent variables, which are, in general, intercorrelated. Its goal is to extract the important information from the data table and to express this information as a set of new orthogonal variables called principal components, PCs (Hervé and Williams, 2010). In this study, PCA was used to discover new variables that best describe the measured soybean yield components.

The first two principal components were varimax-rotated to study the structure of the variables. The aim of the varimax-rotation was to find uncorrelated factors so that each yield variable is strongly correlated with one of the factors and weekly correlated with the other. The analysis and plotting were performed in R 3.6.0 (R Core Team, 2019), using the psych (Revelle, 2018) and ggplot2 (Wickham, 2016) packages.

\section{Results and discussion}

\subsection{Weather conditions during soybean growth (May-August 2017 and 2018)}

The two growing seasons' $T_{a}$ values were $1.3{ }^{\circ} \mathrm{C}$ and $2.4^{\circ} \mathrm{C}(\mathrm{p}<0.001)$ higher in 2017 and 2018, respectively, than the climate norm of 1971-2000. Although the difference in seasonal mean $T_{a}$ between the two studied seasons did not vary $(\mathrm{p}=0.637)$, the extremes $\left(T_{\max }\right.$ : maximum and $T_{\min }$ : minimum temperatures) showed statistically proved deviation (Fig. 1). In the case of the soybean of tropical origin, the upper $T_{a}$ limit of proper crop development is $30^{\circ} \mathrm{C}$. The number of days with $T_{\max }$ above $30{ }^{\circ} \mathrm{C}$ was 38 and 28 during 2017 and 2018 , respectively. For the same time period, the variation in mean $T_{\max }$ did not differ significantly $\left(2017: 27.4{ }^{\circ} \mathrm{C} ; 2018: 27^{\circ} \mathrm{C} ; \mathrm{p}=0.440\right)$. Contrary to the increased number of hot days during 2017 , the mean $T_{\min }$ of this growing season was $1.3{ }^{\circ} \mathrm{C}$ lower than that of the average $T_{\min }$ over $2018(\mathrm{p}<0.001)$. High $T_{a}$ variability was characteristic for the vegetation period of 2017 that might influence the soybean development and yield formation as well.

Limiting to the growing season only, the precipitation in 2017 was characteristic of a dry growing season ( $44.9 \%$ less rainfall than the climate norm; $p=0.006)$, while 2018 received $6.4 \%$ higher $(p=0.046)$ rainfall amount in comparison to the climate norm. Rainfall events had an even distribution in both vegetation periods (Fig. 1). 


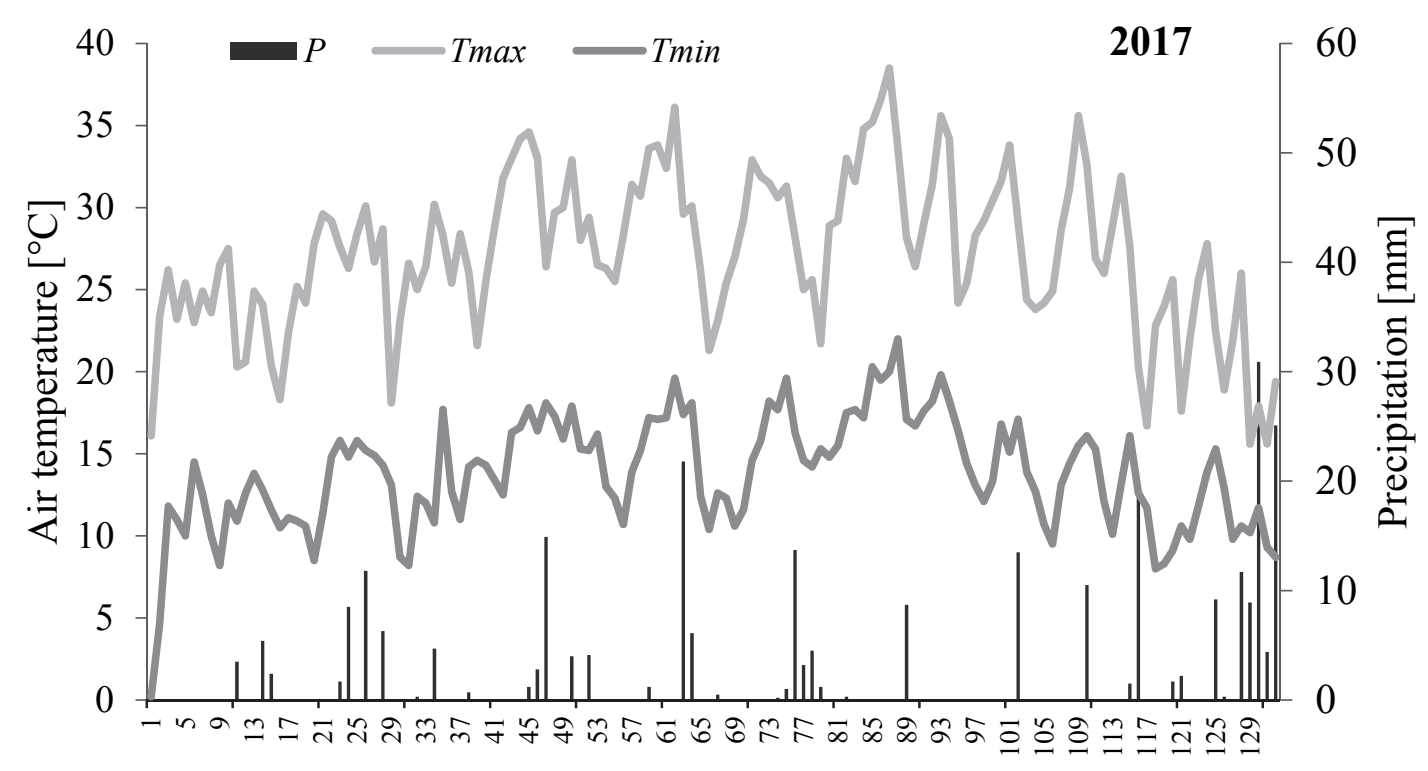

Days after sowing

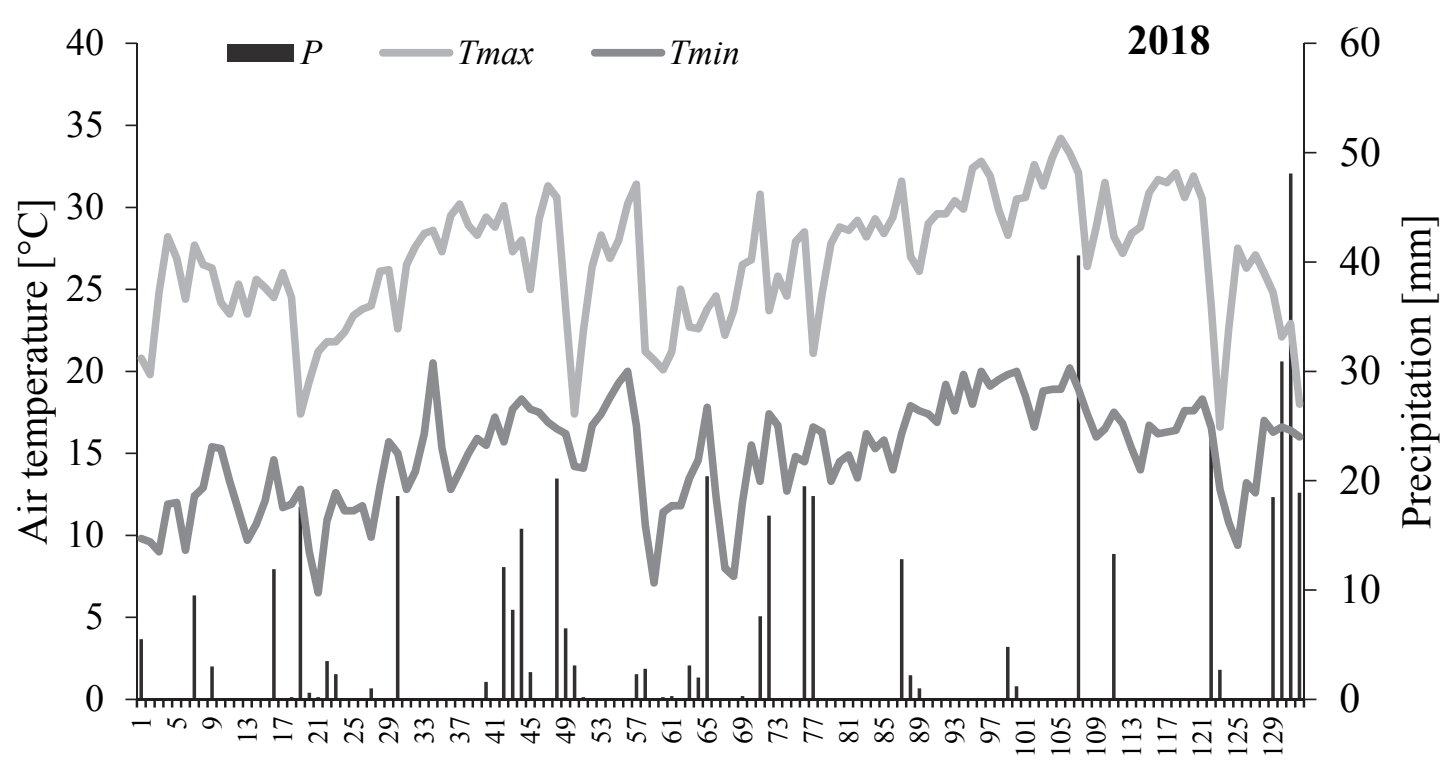

Days after sowing

Fig. 1. Daily air temperature extremes $\left(T_{\max }\right.$ and $\left.T_{\min }\right)$ and daily precipitation sums from the beginning of May to the end of August in 2017 and 2018.

\subsection{ET a of soybean in the growing seasons of 2017 and 2018}

The soybean began to emerge at the end of April in 2017 and at the beginning of May in 2018. At mid-summers, the soybean reached its maximum leaf area index of around 5.0 and 3.5 in ET and RO treatments, respectively, irrespective of 
growing season and/or variety (data not shown). Visible signs of senescence were shown at the end of each August. Later on, due to accelerated senescence, there were no green leaves remaining by the first decade of September. Independently on growing seasons and studied water/variety treatments, the lengths of vegetation cycles hardly varied (115-120 days). The soybean grown in growing chambers of evapotranspirometer (ET) had a few days longer growing seasons than that of the rainfed and RO crops (data is not shown).

Daily mean $E T_{a}$ was analyzed on the basis of soybean's reproductive phenological stages (Fig. 2) after the Fehr and Caviness (1977) scale. The following stages were used: VE - emergence; V3 - third node; V5 - fifth node; R1 - beginning bloom; R2 - full bloom; R3 - beginning pod; R4 - full pod; R5 beginning seed; R6 - full seed; R7 - beginning maturity; R8 - full maturity. At unlimited watering, a similar seasonal $E T_{a}$ pattern was observed, irrespective to studied season; low daily mean $\mathrm{ET}_{\mathrm{a}}$ of about $1.8 \mathrm{~mm}$ were measured in VE, while peak daily $E T_{a}$ of $9.8 \mathrm{~mm}$ in R4 (Sig in 2017) and $7.0 \mathrm{~mm}$ in R5 (Sin in 2018) were detected. Independently on variety/season, a somewhat higher daily mean $E T_{a}$ of 3-4 mm in R8 were observed in comparison to the average $E T_{a}$ of VE. The $E T_{a}$ in different phenological phases of the two studied varieties hardly varied. Unexpectedly, during mid-summers, the $E T_{a}$ of unlimited watering in the warmer 2018 were lower than the $E T_{a}$ during the cooler 2017. The soybean is known to be extremely sensitive to air humidity as a tropical origin crop; the crops prefer humid (wet) weather conditions. Probably the increased number of days with higher RH during the wetter 2018 explains the lower $E T_{a}$ related to higher water losses over 2017 (Fig. 3). Probably the driving force of $E T_{a}$, the varied air humidity, might impact the $E T_{a}$ events to a greater extent than the $T_{a}$ throughout the studied growing seasons.

Water restriction modified both the shape of the $E T_{a}$ course (smoothed out curves) and the mean $E T_{a}$ in both seasons. Declines in seasonal mean $E T_{a}$ rates of water withdrawn crops ranged from $65.8 \%$ (Sig 2018; $<<0.001$ ) to $77.8 \%$ ( $\operatorname{Sin}$ 2018; $\mathrm{p}<0.001$ ) during the study period. It is important to mention that the water deprivation was limited to flowering only.

Despite different variety standards provided by the crop breeders and irrespective of water supply, no significant impact in $E T_{a}$ between the two varieties was observed $(p=0.244-0.697)$.

Seasonal $E T_{a}$ totals varied from 276.1 (Sig RO) to $669.2 \mathrm{~mm}$ (Sin ET) in 2017 and 316.8 (Sin RO) to $720.6 \mathrm{~mm}$ (Sin ET) in 2018 among the treatments. The only significant difference of $51.4 \mathrm{~mm}(\mathrm{p}<0.017)$ in $\operatorname{Sin} E T_{a}$ sums between 2017 and 2018 was registered at unlimited watering. $E T_{a}$ totals of crops with unlimited water supply in this study were close to the $E T_{a}$ sum of $650 \mathrm{~mm}$ by Candogan and Yazgan (2016) measured in irrigated soybean grown in Turkey $\left(40^{\circ} \mathrm{N}, 28^{\circ} \mathrm{E}\right)$. The same authors reported that the water withdrawn soybean's $E T_{a}$ total was at about the half of the fully irrigated ones. 

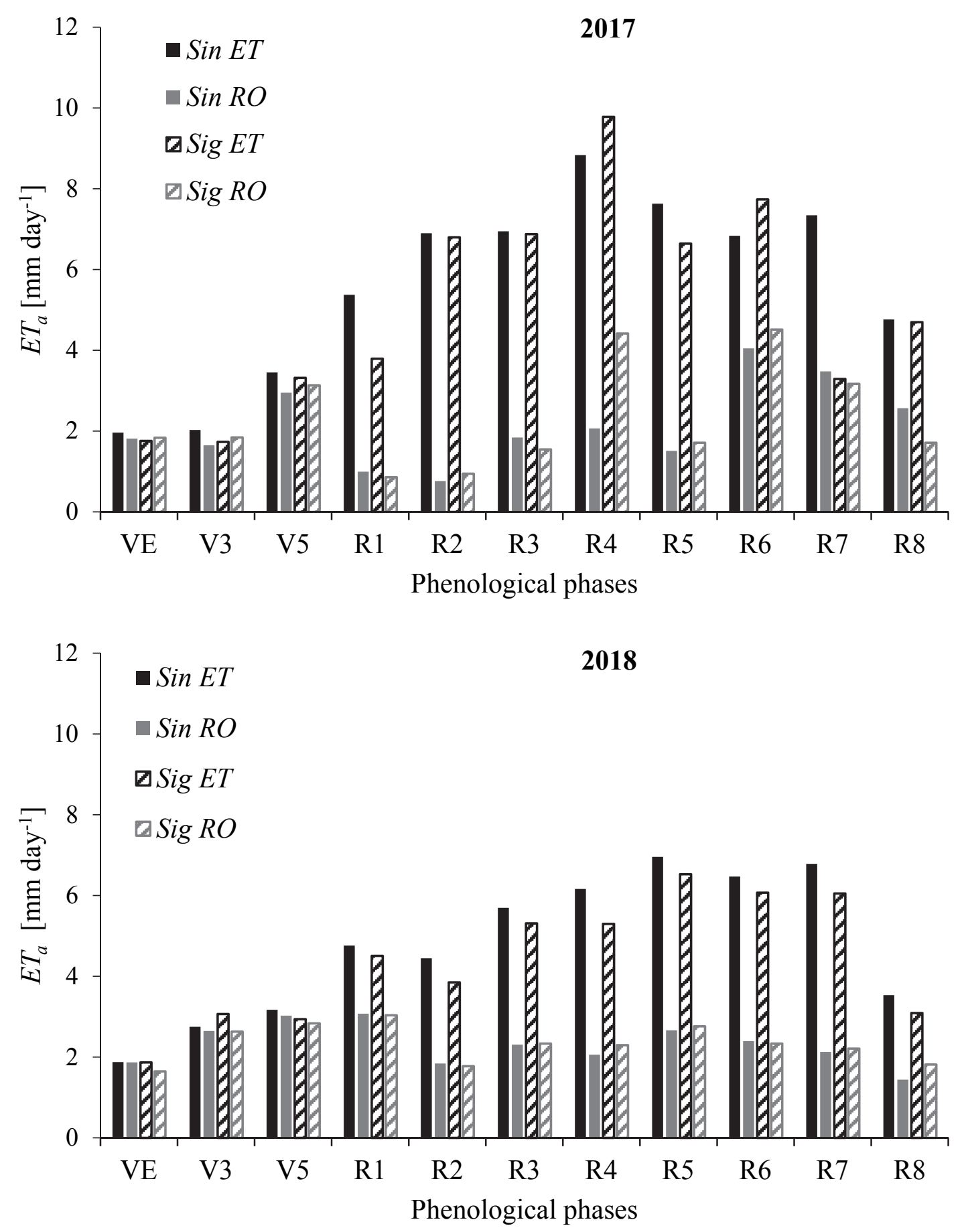

Fig. 2. Daily mean evapotranspiration of phenological stages from soybean in the growing seasons of 2017 and 2018. Abbreviations: ET - evapotranspirometer with unlimited water supply; RO - 50\% water deprivation in evapotranspirometer; Sin - Sinara; Sig - Sigalia. 


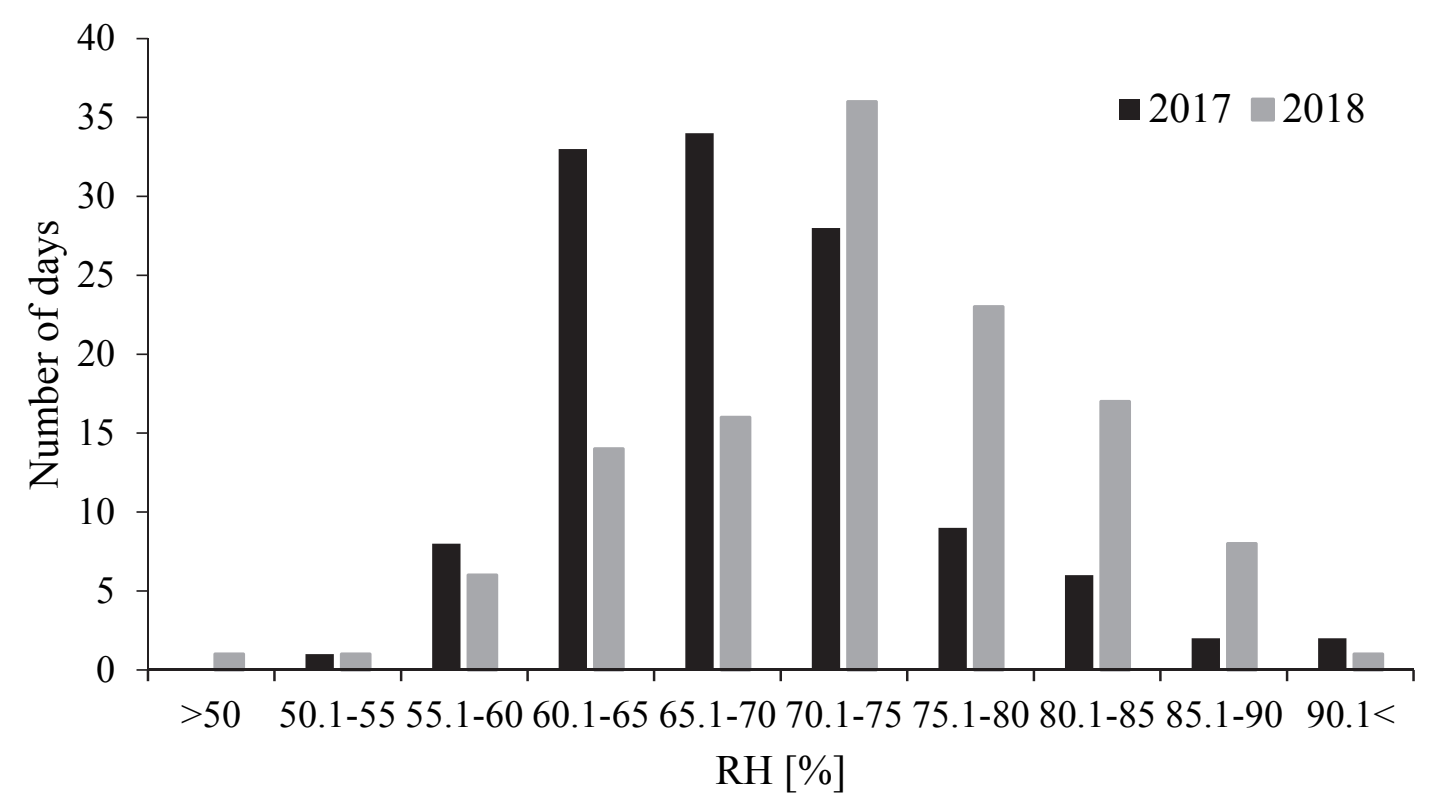

Fig. 3. Distribution of the number of days with different daily mean relative humidity values (\%) during the growing seasons of 2017 and 2018 at Keszthely.

\subsection{Yield component analysis by $P C A$}

The most important yield component, the seed yield, as an example is emphasized in Fig. 4.

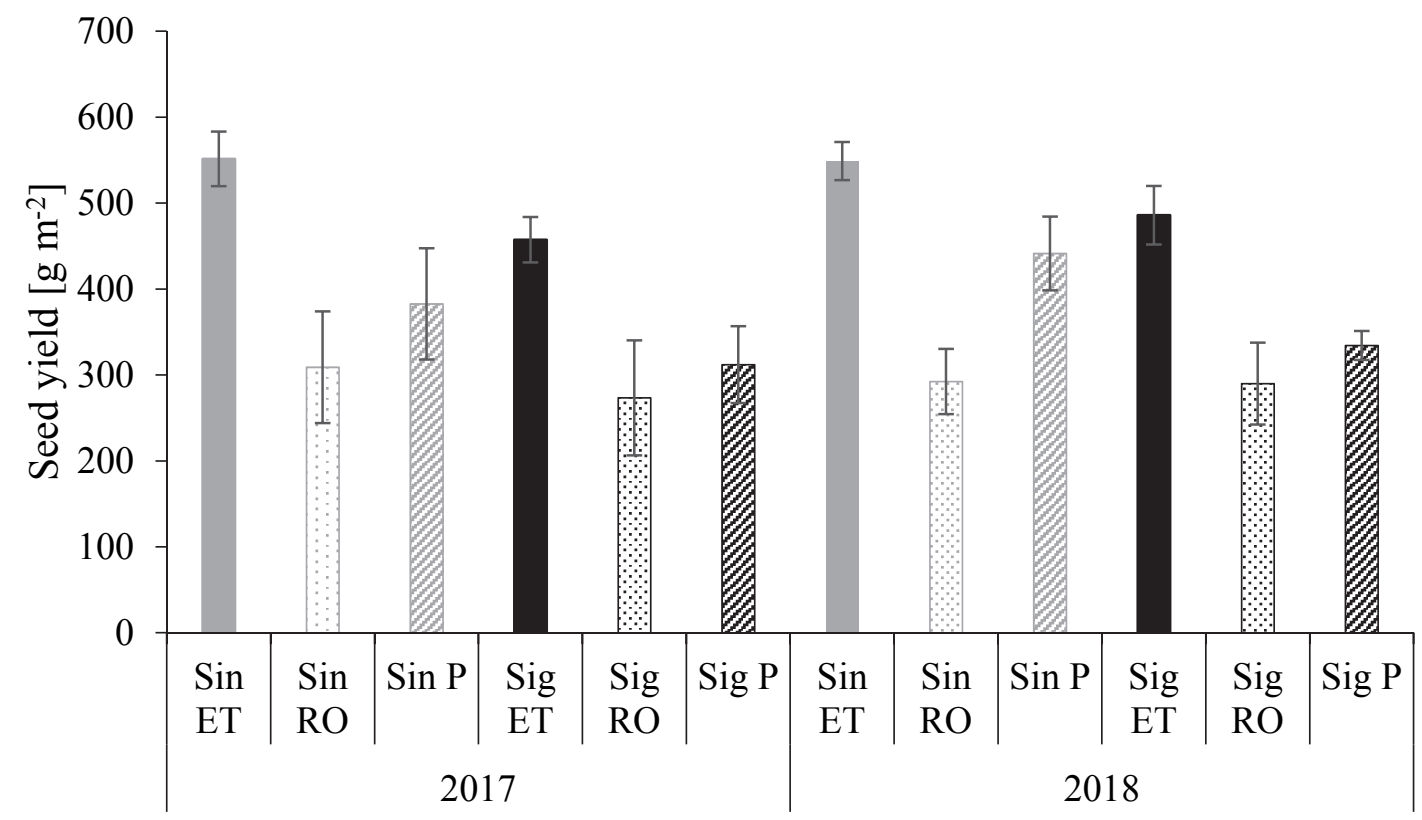

Fig. 4. Seed yield of soybean varieties Sin and Sig in three different water levels (ET: unlimited water; RO: water withdrawn crops; P: rainfed soybean) in 2017 and 2018. 
The seed yield advantage of ET was clearly visible in both varieties. Similarly, the detrimental impact of water deprivation also left no doubt in the case of RO treatments.

The yield-related variables were analyzed with principal component analysis (PCA). This analysis has of primary importance as it accounts the impacts of different yield components together. Two PCs were distinguished; PC1 and PC2 accounted for $63 \%$ and $20 \%$ of the total variance, respectively. Projecting the data onto the plane defined by the first two PCs, the observations from different years were well separated (Fig. 5). The loading vectors of the yield-related variables are presented along with the PCA scores in a biplot (Fig. 6).

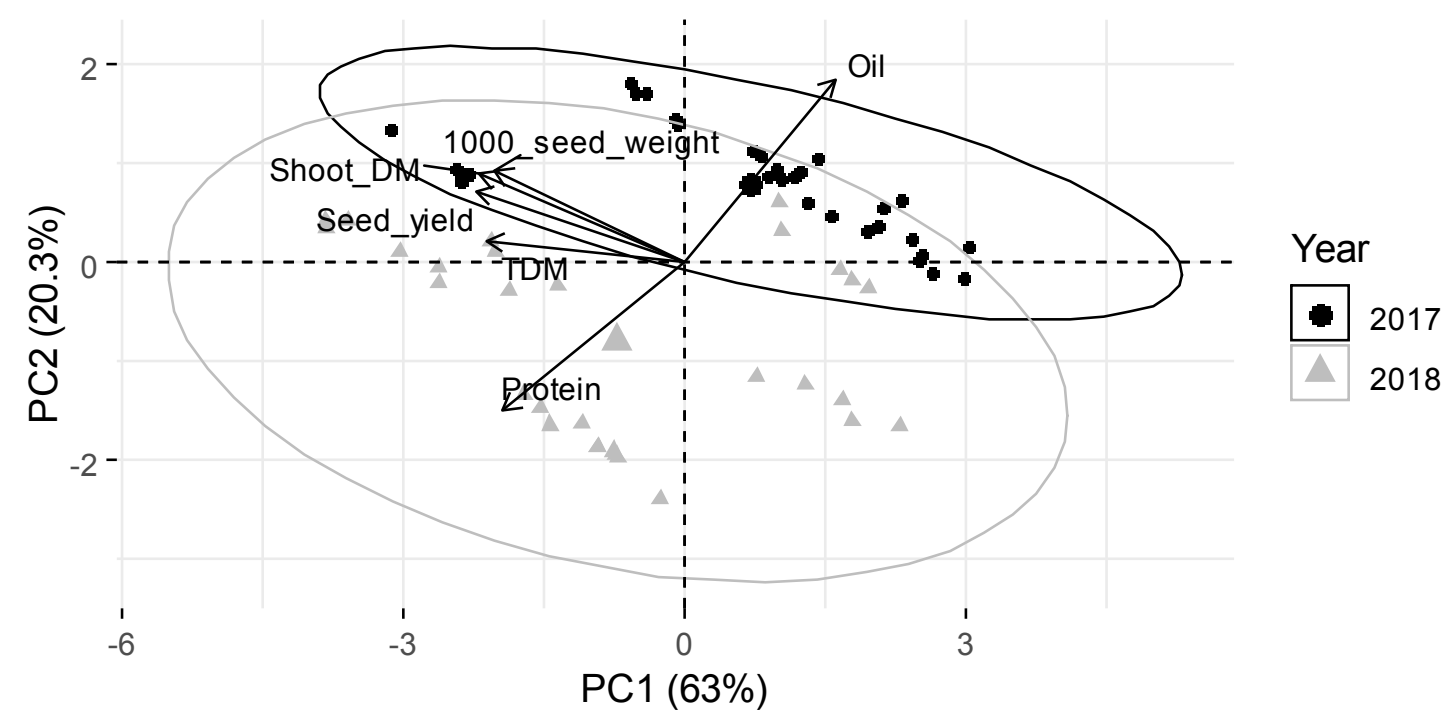

Fig. 5. Observations from the two years projected onto the plane of the first two principal components as well as the loading vectors of the observed variables. PCA was performed with the following six variables: TDM, shoot dry matter, seed yield, 1000-seed weight, protein and oil contents.

It could be seen that PC1 had positive loadings on oil content and negative loadings on all other variables. Observations from different years were presented separately in Fig. 6. 

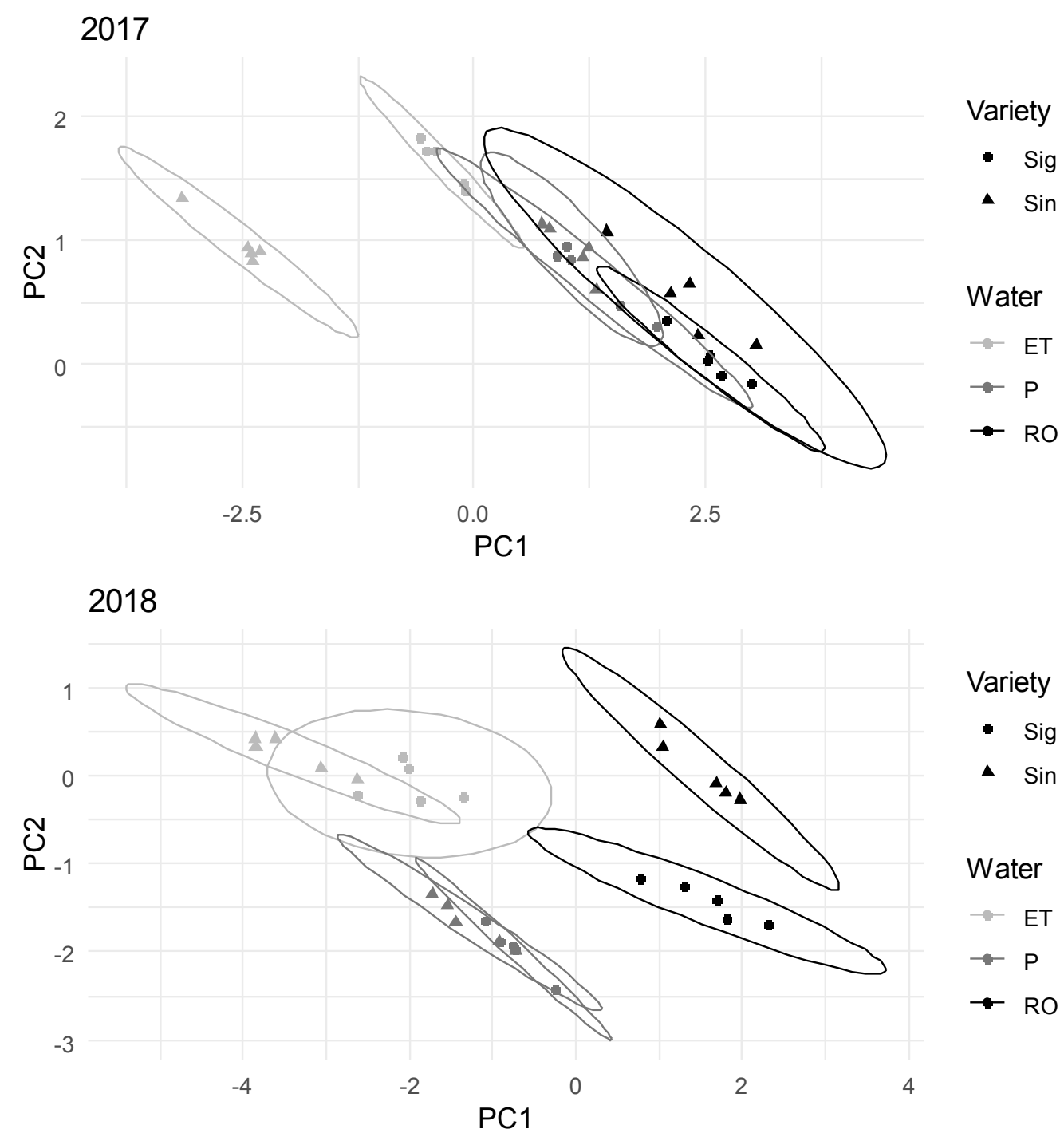

Fig. 6. Observations by variety and treatment projected onto the plane of the first two principal components (upper 2017 and lower 2018). PCs were extracted from the variables: TDM, shoot dry matter, seed yield, 1000-seed weight, protein and oil contents.

Groups from left to right represent treatment-variety combinations with higher oil, lower protein content, and lower yield amount. In 2017, the majority of the treatment-variety combinations overlapped, only the Sin ET was separated along the first principal component. Separation of Sin ET was due to the low oil content and high other values. RO treatments had been shifted to the right due to lower yield amount. Separation of the RO treatments was even more pronounced in 2018, confirming the effect of water withdrawal on the crop yield components. In that year, P and ET treatments were also be well separated by PC2. PC2 was positively correlated with yield quantity related variables and negatively 
correlated with protein content. The shift of ET treatments was due to lower protein content and higher yield quantity. Observations from different varieties overlapped in the case of treatment $\mathrm{P}$ in both years (Fig. 6). In case of the treatment ET, the varieties overlapped in 2018 but were separated in 2017. It was reversed in case of treatment RO, they overlapped in 2017 and were separated in 2018 (Fig. 6).

The first two PCs were varimax-rotated to get factors having a high and a low loading on each yield variable. The varimax-rotated PCs and the loading vectors of the yield variables presented a clear structure (see also Fig. 5): the separation of the two different seed yield attributes (qualitative ones: oil and protein contents; quantitative ones: 1000-grain weight, TDM, shoot DM, seed yield).

The rotated PCs are called factors. The variance explained by the factors remained $83.3 \%$ after the rotation. The first factor explained $50.3 \%$ of the total variance. It had high loadings on the seed yield, 1000-grain weight, shoot $D M$, and $T D M$ variables. The second factor explained $33 \%$ of the total variance, and it had high loadings on the oil and protein contents (Table 1).

Table 1. Factor loadings after varimax rotation. The loadings with an absolute value above 0.4 are in bold. The $\mathrm{h}^{2}$ values are communalities. Loadings are the correlations between the observed variables and the factors. Communality is the proportion of the variance in an observed variable explained by the two factors.

\begin{tabular}{|c|c|c|c|}
\hline & Factor1 & Factor2 & $\mathbf{h}^{2}$ \\
\hline Seed yield $\left[\mathrm{kg} \mathrm{m}^{-2}\right]$ & 0.885 & 0.239 & 0.840 \\
\hline 1000-grain weight $[\mathrm{g}]$ & 0.863 & 0.131 & 0.762 \\
\hline Shoot DM $\left[\mathrm{kg} \mathrm{m}^{-2}\right]$ & 0.909 & 0.173 & 0.856 \\
\hline $\mathrm{TDM}\left[\mathrm{kg} \mathrm{m}^{-2}\right]$ & 0.739 & 0.379 & 0.690 \\
\hline Oil [\%] & -0.133 & -0.955 & 0.930 \\
\hline Protein $[\%]$ & 0.313 & 0.906 & 0.919 \\
\hline Proportion of explained variance & 0.503 & 0.33 & \\
\hline
\end{tabular}

The sum of squares of the loadings are called communalities or common variance, they represent the proportion of variance of each variable explained by the factors. Each communality was above $69 \%(62.9 \%)$. The oil and the protein percentages had the highest communalities over $91 \%$ (92\%). The first factor could be interpreted as the quantity of the seed yield, the second as the quality of the seed. $T D M$ was the only variable having relatively high loadings on both factors. 
This suggested that TDM is connected to both the nutritional content and the amount of the seed. The oil and the protein percentages were strongly negatively correlated as reported by Marega Fihlo et al. (2001) and Latifi (1989) previously.

\section{Conclusions}

Water deprivation in soybean changed the shape of $E T_{a}$ curves and the amount of $E T_{a}$ totals in both growing seasons. Irrespective of season and/or variety, declines in seasonal mean $E T_{a}$ rates of RO crops were at about $70 \%$ as compared to $E T_{a}$ measured at unlimited watering.

Surprisingly, significant difference in seed yield between the two varieties with different water needs was only observed at unlimited watering level. Variety Sin showed 18.6\% and 12.2\% higher seed yield in 2017 and 2018, respectively, as compared to Sig. The negative impact of water deprivation during flowering was almost the same in both soybean varieties.

The almost unmanageable elaborating interactions between the yield components of soybean were analyzed using the PCA. The effects of three water supplies were summarized in the experimental plots presenting the observations projected onto the plane of the first two PCs. Plants in the RO treatment were clearly separated from those in the other treatments towards a greater seed oil content and lower yield mass. There was no significant difference between the varieties in rainfed treatment, P. As compared to variety Sig, variety Sin produced better yield in unlimited water level in 2017, weather conditions and its seed had greater oil and lower protein content in RO treatment in 2018 conditions. After varimax rotation, the loading vectors of the yield variables presented a clear structure. The first factor could be interpreted as the quantity of the soybean yield, while the second as the quality of the seed.

Acknowledgements: The research leading to these results has received funding from the Hungarian Government and the European Regional Development Fund of the European Union in the frames of the Széchenyi 2020 Programme, under project number GINOP-2.3.2-15-2016-00029. The publication was also supported by the EFOP-3.6.3-VEKOP-16-2017-00008 project. The project is co-financed by the European Union and the European Social Fund. Special thanks to Karintia Ltd. for supporting us with good-quality corn-free soybean seed.

\section{References}

Anapalli, S.S., Fisher, D.K., Reddy, K.N., and Wagle, P., 2018: Quantifying soybean evapotranspiration using eddy covariance approach. Agric. Water Manage. 209, 228-239. https://doi.org/10.1016/j.agwat.2018.07.023

Anda, A., Simon, B., Soós, G., Teixeira da Silva J.A., and Kucserka, T., 2019: Crop-water relation and production of two soybean varieties under different water supplies. Theor. Appl. Climatol. 137, 1515-1528. https://doi.org/10.1007/s00704-018-2660-9 
Aydinsakir, K. 2018: Yield and Quality Characteristics of Drip-Irrigated Soybean under Different Irrigation Levels. Agron. J. 110, 1473-1481. https://doi.org/10.2134/agronj2017.12.0748

Candogan, B.N. and Yazgan, S., 2016. Yield and quality response of soybean to full and deficit irrigation at different growth stages under sub-humid climatic conditions. J. Agric. Sci. 22, 129-144. https://doi.org/10.1501/Tarimbil_0000001375

Candogan, B.N., Sincik, M., Buyukcangaz, H., Demirtas, C., Goksoy, A.T. and Yazgan, Yield, S., 2013: Quality and crop water stress index relationships for deficit-irrigated soybean [Glycine max (L.) Merr.] in sub-humid climatic conditions. Agric. Water Manage. 118, 113-121. https://doi.org/10.1016/j.agwat.2012.11.021

Fehr, W.R. and Caviness, C.E., 1977: Stages of soybean development. Spec. Rep. 80, Iowa State University, Ames, Iowa.

Hervé, A and Williams, L.J., 2010: Principal Component Analysis. John Wiley and Sons, Inc. WIREs Comp Stat 2, 433-59. https://doi.org/10.1002/wics.101

Kross, A., Lapen, D.R., McNairn, H., Sunohara, M., Champagne, C., and Wilkes, G., 2015: Satellite and in situ derived corn and soybean biomass and leaf area index: Response to controlled tile drainage under varying weather conditions. Agr. Water Manage. 160, 118-13. https://doi.org/10.1016/j.agwat.2015.06.007

Latifi, N., 1989: Yield and morphological response of soybean to time of irrigation and sowing date. Diss. Abstract Int. 40, 5088-5098.

Marega Filho, M., Destro, D., Miranda, L.A., Spinosa, W.A., Carrão-Panizzi, M.C., and Montalván, R., 2001: Relationships among oil content, protein content and seed size in soybeans. Brazilian Arch. Biol. Technol. 44, 23-32. https://doi.org/10.1590/S1516-89132001000100004

Momen, N.N., Carlson, R.E., Shaw, R.H., and Arjmand O., 1979: Moisture-stress effects on the yield components of two soybean cultivars. Agron. J. 71, 86-90. https://doi.org/10.2134/agronj1979.00021962007100010022x

$R$ Core Team, 2019. R: A language and environment for statistical computing. R Foundation for Statistical Computing, Vienna, Austria. URL: https://www.R-project.org/.

Revelle, $W$. , 2018. psych: Procedures for Personality and Psychological Research, Northwestern University, Evanston, Illinois, USA. https://CRAN.R-project.org/package=psych Version $=1.8 .12$

Wei, Z., Paredes, P., Liu, Y., Chi, W.W, and Pereira, L.S., 2015. Modelling transpiration, soil evaporation and yield prediction of soybean in North China Plain. Agric. Water Manage. 147, 43-53. https://doi.org/10.1016/j.agwat.2014.05.004

Wickham, H., 2016: Elegant Graphics for Data Analysis. Springer-Verlag New York. 